\title{
KONTRIBUSI DAYA LEDAK OTOT LENGAN DAN DAYA LEDAK OTOT TUNGKAI TERHADAP HASIL SMASH
}

(Studi Deskriptif Pada Siswa Esktrakurikuler Bola Voli di Ma AL-Riyad)

Muhamad Rivan Syukur ${ }^{1}$, Budiarto $^{2}$, Ervan Kastrena $^{3}$

Pendidikan Jasmani Kesehatan dan Rekreasi

Universitas Suryakancana, Fakultas Keguruan dan Ilmu Pendidikan rivansykur25@gmail.com ervankastrena@unsur.ac.id

\begin{tabular}{l}
\hline Info Artikel \\
\hline Sejarah Artikel: \\
Diterima Maret 2019 \\
Disetujui April 2019 \\
Dipublikasikan Juni 2019
\end{tabular}

Keyword:

Daya Ledak Otot

Lengan,Daya Ledak Otot

Tungkai, Smash

\begin{abstract}
Abstrak
Daya Ledak merupakan komponen kondisi fisik yang sangat penting serta berguna untuk menunjang dalam melakukan kegiatan fisik khususnya untuk melakukan teknik dasar smash.Tujuan dari penelitian ini adalah untuk mengetahui secara akurat mengenai kontribusi daya ledak otot lengan dan daya ledak otot tungkai terhadap hasil smash. Metode penelitian yang diterapkan adalah deskrptif korelasi dengan desain penelitian korelasional. Instrumen smash yang digunakan dalam penelitian adalah menggunakan nomor di setiap sisi lapangan. Analisis data menggunakan program SPSS versi 17. Hasil penelitian menunjukan (1) Ada hubungan yang signifikan antara daya ledak otot lengan terhadap keberhasilan dalam melakukan smash pada atlet bola voli di Ma AL-Riyad (r=.417), (2) Ada hubungan yang signifikan antara daya ledak otot tungkai terhadap keberhasilan dalam melakukan smash pada atlet bola voli di Ma AL-Riyad ( $\mathrm{r}=612$ ), (3) Ada hubungan yang signifikan secara bersamaan antara daya ledak otot lengan dan daya ledak otot tungkai terhadap keberhasilan dalam melakukan smash pada atlet bola voli di Ma AL-Riyad $\left(\mathrm{R}^{\mathrm{yx} 1 \times 2}=0.630\right)$. Kesimpulan menunjukan bahwa besarnya korelasi bersamaan antara daya ledak otot lengan dan daya ledak otot tungkai dengan kemampuan smash dihitung dengan koefisien korelasi yang kuat.
\end{abstract}

\section{Abstrack}

Explosive power is a component of physical condition that is very important and useful to support physical activities, especially to perform basic smash techniques. The purpose of this study is to find out accurately the contribution of arm muscle explosive power and leg muscle explosive power to smash results. The research method applied is descriptive correlation with correlational research designs. The smash instrument used in the study was to use numbers on each side of the field. Data analysis used SPSS version 17. The results showed (1) there was a significant relationship between arm muscle explosive power and the success in smashing volleyball athletes at Ma AL-Riyad ( $r=.417)$, (2) there was a significant relationship significant between the leg muscle 


explosive power to the success in smashing volleyball
athletes in Ma AL-Riyad $(r=612)$, (3) There is a
simultaneously significant relationship between the arm
muscle explosive power and the leg muscle explosive power
to the success in smashing in volleyball athletes at Ma $A L-$
Riyad (Ryxlx2 =0.630). The conclusion shows that the
magnitude of the concurrent correlation between arm muscle
explosive power and leg muscle explosive power with the
smash ability is calculated with a strong correlation
coefficient

(C) 2019 Universitas Suryakancana

Alamat korespondensi: e-ISSN : 2721-7175 (online)

E-mail: Adirahadian@unsur.ac.id p-ISSN : 2089-2341 (cetak)

\section{PENDAHULUAN}

Dalam permainan bola voli untuk mendapatkan prestasi yang gemilang, maka seorang atlet harus memiliki penguasaan teknik dasar dan kondisi fisik yang baik. Dalam permainan bola voli ada beberapa macam teknik dasar yang sangat menunjang untuk dapat bermain bola voli, antara lain servis, passing, smash dan block. Smash merupakan salah satu teknik dasar dalam permainan bola voli yang memiliki peran yang sangat penting untuk membuat sebuah serangan dan mendapatkan sebuah angka. Smash pada dasarnya sebuah pukulan yang keras yang sering digunakan oleh para atlet untuk mendapatkan sebuah angka, oleh karena itu, agar atlet dapat bermain bola voli dengan baik serta dapat meraih prestasi yang gemilang dalam cabang olahraga bola voli, maka seorang pelatih perlu memperhatikan faktor teknik dasar khususnya smash. Selain itu, apabila seorang atlet ingin mencapai prestasi yang maksimal, maka faktor kondisi fisik secara bersamaanpun harus ditingkatkan. Menurut Ahmadi (2007, hlm. 64) menjelaskan bahwa "Bola voli termasuk jenis olahraga yang banyak mengandalkan fisik, maka kondisi fisik pemain sangat penting dalam menunjang efektivitas permainan."

Terkait penjelasan tersebut, untuk menghasilkan keterampilan smash yang maksimal, maka dibutuhkan komponen fisik yaitu daya ledak otot lengan dan daya ledak otot tungkai. Daya ledak otot lengan pada dasarnya sangat berguna untuk menghasilkan pukulan yang keras. Hal tersebut dipertegas oleh Ahmadi, (2007, hlm. 14) "Kaitannya dalam pelaksanaan smash, daya ledak otot lengan memiliki peran untuk memberikan tenaga sewaktu lengan memukul bola yang sekeraskerasnya." Daya ledak otot lengan merupakan kondisi fisik yang tidak dapat dipisahkan dan merupakan penunjang utama gerakan yaitu kekuatan otot dan 
kecepatan otot untuk mengarahkan tenaga yang maksimal.

Daya ledak otot lengan merupakan salah satu faktor sangat penting dan harus diperhatikan dalam permainan bola voli, terutama pada saat melakukan pukulan, sehingga dengan memiliki daya ledak otot lengan yang baik, akan menghasilkan smash yang lebih baik pula. Sebaliknya apabila seorang atlet memiliki daya ledak otot lengan yang lemah, maka dapat menyebabkan pukulan tidak terlalu keras sehingga lebih mudah untuk dibendung oleh lawan. Selain harus memiliki daya ledak otot lengan yang besar, untuk menghasilkan smash yang sempurna harus di tunjang oleh daya ledak otot tungkai pula.

Daya ledak otot tungkai sangat berguna untuk menghasilkan loncatan yang tinggi, dengan loncatan yang tinggi seorang atlet dapat dengan mudah untuk memukul bola. Sama halnya dengan pendapat Ahmadi, (2007, hlm. 14) "Kaitannya dalam pelaksanaan smash, daya ledak otot tungkai memiliki peran untuk memberikan tenaga sewaktu melakukan loncatan sehingga lengan dapat memukul bola yang sekeras-kerasnya." Berdasarkan penjelasan tersebut, dapat disimpulkan bahwa untuk menghasilkan gerakan smash yang sempurna, seorang atlet sangat membutuhkan komponen daya ledak otot lengan dan daya ledak otot tungkai yang besar.

Berdasarkan hasil survey dan informasi dari guru penjas maupun pelatih bola voli di Ma AL-Riyad, peneliti mencatat data evaluasi atlet yakni masih jarang meraih kemenangan pada saat bertanding dan saat berlatih terlihat banyak atlet yang belum mampu melakukan smash dengan baik, pukulan smash yang dihasilkan kurang keras dan cepat, sehingga dapat dengan mudah di bendung oleh lawan. Berdasarkan pengamatan tersebut, peneliti berasumsi bahwa hal itu ada kaitannya dengan daya ledak otot lengan dan daya ledak otot tungkai yang tidak terlatih dengan baik. Mengacu kepada permasalahan tersebut, maka peneliti merasa penting untuk melakukan penelitian ini. Dengan diadakannya penelitian ini, dapat memberikan informasi dengan jelas dan akurat kepada guru penjas dan pelatih mengenai kontribusi dari daya ledak otot lengan dan daya ledak otot tungkai terhadap keberhasilan dalam melakukan smash. Jika penelitian ini menunjukan hasil yang signifikan, nantinya guru penjas maupun pelatih bola voli dapat membuat suatu program latihan untuk meningkatkan kemampuan daya ledak otot lengan dan daya ledak otot tungkai atlet, sehingga dapat menunjang atlet tersebut untuk meraih prestasi secara maksimal.

Berdasarkan latar belakang dan analisis masalah di atas, maka peneliti bertujuan untuk mengetahui dan menguji hubungan daya ledak otot lengan dan daya ledak otot tungkai terhadap keberhasilan dalam melakukan smash pada atlet bola voli di Ma AL-Riyad. 


\section{METODE}

Metode yang digunakan dalam penelitian ini adalah metode penelitian deskiptif korelasional. Menurut Arikunto (2010, hlm. 4) bahwa "Penelitian korelasional adalah penelitian yang dilakukan oleh peneliti untuk mengetahui tingkat hubungan antara dua variabel atau lebih, tanpa melakukan perubahan, tambahan atau manipulasi terhadap data yang memang sudah ada". Desain penelitian korelasional $r x^{1}, x^{2} y$. Untuk lebih jelas mengenai desain penelitian yang digunakan dalam penelitian ini, maka dapat dilihat pada Gambar 3.1.

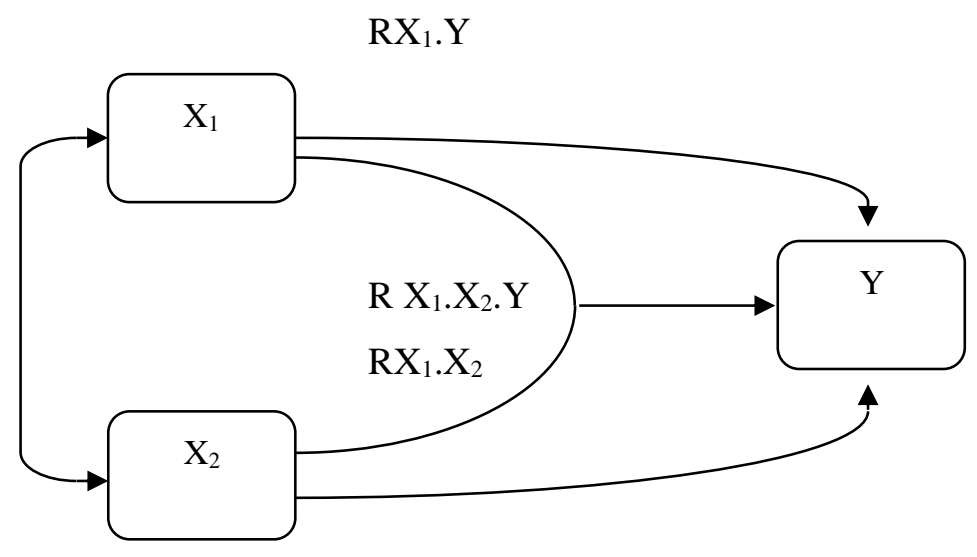

$\mathrm{RX}_{2} \cdot \mathrm{Y}$

Gambar 3.1. Desain Penelitian

Sumber : Sugiyono (2016, hlm. 71)

Target populasi dalam penelitian ini adalah atlet bola voli di Ma AL-Riyad, yang berjumlah 30 orang. Teknik penyempelan yang digunakan adalah sampling jenuh. Sampling jenuh adalah teknik penentuan sampel bila semua anggota populaitas dijadikan sebagai sampel (Sugiyono, 2016, hlm. 85). Hal ini sering dilakukan bila jumlah populasi relative kecil, kurang dari 30 orang, atau penelitian yang ingin membuat generalisasi dengan kesalahan yang sangat kecil. Istilah lain sampel jenuh adalah sensus, dimana semua anggota populasi dijadikan sampel. Dikarenakan teknik sampling yang digunakan dalam penelitian ini adalah sampling jenuh, maka semua populasi yang berjumlah 30 atlet, dijadikan sampel dalam penelitian ini.

Instrumen untuk mengukur daya ledak lengan dan gelang bahu pada anak laki-laki atau perempuan yang berusia 12 tahun hingga tingkat mahasiswa, dengan menggunakan tes two hand medicine ball put. Tes ini memiliki tingkat validitas sebesar 0,77 dan reliabilitas sebesar 0,81 (Nurhasan \& Setiawan, 2017, hlm. 175). Istrumen untuk mengukur daya ledak otot tungkai pada anak laki-laki atau perempuan yang berusia 12 tahun hingga tingkat mahasiswa, dengan menggunakan alat jump multy digital. Instrumen selanjutnya yang digunakan dalam penelitian adalah tes sejauh mana kemampuan siswa dalam melakukan smash pada permainan bola voli. alat ukurnya denngan menggunakan nomor di setiap sisi lapangan sesuai penilaian yang akan di berikan dan mengunakan alat ukur angka. Tes smash dari Nurhasan \& Setiawan (2017, hlm. 225) dengan reabilitas tes 0,94 dan validitas tes 0,84 
$27 \mid$ Muhamad Rivan Syukur ${ }^{1}$, Budiarto ${ }^{2}$, Ervan Kastrena ${ }^{3}$

Kontribusi Daya Ledak Otot Lengan Dan Daya Ledak Otot Tungkai Terhadap Hasil Smash

\begin{tabular}{|c|c|c|c|}
\hline Variabel & Sig & $\alpha$ & Kesimpulan \\
\hline $\begin{array}{c}\text { Daya Ledak } \\
\text { Otot Lengan } \\
\left(\mathrm{X}^{1}\right)\end{array}$ & .126 & 0,05 & $\begin{array}{c}\text { Data } \\
\text { Normal }\end{array}$ \\
\hline $\begin{array}{c}\text { Daya Ledak } \\
\text { Otot } \\
\text { Tungkai } \\
\left(\mathrm{X}^{2}\right)\end{array}$ & .077 & 0,05 & $\begin{array}{c}\text { Data } \\
\text { Normal }\end{array}$ \\
\hline $\begin{array}{c}\text { Kemampua } \\
\mathrm{n} \text { Smash }\end{array}$ & .212 & 0,05 & $\begin{array}{c}\text { Data } \\
\text { (Y) }\end{array}$ \\
& & \\
\hline
\end{tabular}

batrey test untuk usia 16-18 tahun.

Analisis data menggunakan SPSS versi 17.

\section{Hasil}

\section{Deksriptif Data}

Tabel 1. Deskriptif Data

\begin{tabular}{|c|c|c|c|c|c|}
\hline & $\mathrm{N}$ & $\begin{array}{l}\text { Minim } \\
\text { um }\end{array}$ & $\begin{array}{l}\text { Maxi } \\
\text { mum }\end{array}$ & $\begin{array}{l}\text { Me } \\
\text { an }\end{array}$ & $\begin{array}{c}\text { Std. } \\
\text { Deviatio } \\
n\end{array}$ \\
\hline $\begin{array}{c}\text { Daya } \\
\text { Ledak } \\
\text { Otot } \\
\text { Lengan } \\
\left(\mathrm{X}^{1}\right)\end{array}$ & 30 & 1 & 7 & $\begin{array}{r}4.5 \\
7\end{array}$ & 2.144 \\
\hline $\begin{array}{c}\text { Daya } \\
\text { Ledak } \\
\text { Otot } \\
\text { Tungkai } \\
\left(\mathrm{X}^{2}\right)\end{array}$ & 30 & 10 & 25 & $\begin{array}{r}14 . \\
60\end{array}$ & 4.753 \\
\hline $\begin{array}{c}\text { Smash } \\
(\mathrm{Y})\end{array}$ & 30 & 10 & 20 & $\begin{array}{r}14 . \\
07\end{array}$ & 2.888 \\
\hline
\end{tabular}

diperoleh nilai rata-rata dari setiap variabel, variabel $\mathrm{X}^{1}$ nilai rata-rata sebesar 4.57 dan simpangan baku sebesar 2.144 selanjutnya variabel $X^{2}$ nilai rata-rata sebesar 14.60 dan simpangan baku sebesar 4.753. Sedangkan variabel Y nilai rata-rata sebesar 14.07 dan simpangan baku sebesar 2.888 dan simbol $\mathrm{N}$ sebanyak 30 menunjukan sampel yang digunakan dalam penelitian ini.

\section{Pengujian Normalitas}

Tabel 2. Hasil Pengujian Normalitas

Berdasarkan Tabel 2 di atas diperoleh nilai sig dari variabel daya ledak otot lengan $\left(\mathrm{X}^{1}\right)$ sebesar $.126>\alpha 0.05$. Selanjutnya variabel daya ledak otot tungkai $\left(\mathrm{X}^{2}\right)$ nilai sig sebesar $.077>\alpha 0.05$. Sedangkan variabel kemampuan smash (Y) nilai sig yang diperoleh sebesar .212> $\alpha \quad 0.05$. Karena semua variabel memperoleh nilai sig lebih besar dari nilai $\alpha 0.05$, maka artinya data berdistribusi normal. Karena semua data berdistribusi normal maka langkah selanjutnya melakukan uji homogenitas data.

\section{Hasil Pengujian Homogenitas}

Tabel 3. Hasil Pengujian Homogenitas

\begin{tabular}{|c|c|c|c|}
\hline Variabel & Sig & $\alpha$ & Keterangan \\
\hline $\begin{array}{c}\text { Daya Ledak } \\
\text { Otot Lengan } \\
\left(\mathrm{X}^{1}\right)\end{array}$ & & & \\
\hline $\begin{array}{c}\text { Daya Ledak } \\
\text { Otot Tungkai } \\
\left(\mathrm{X}^{2}\right)\end{array}$ & .308 & 0,05 & $\begin{array}{c}\text { Data } \\
\text { Homogen }\end{array}$ \\
\hline $\begin{array}{c}\text { Kemampuan } \\
\text { Smash } \\
\text { (Y) }\end{array}$ & & & \\
\hline
\end{tabular}

Dari Tabel 3 di atas dapat dilihat bahwa nilai sig pada variabel daya ledak otot lengan $\left(\mathrm{X}^{1}\right)$, variabel daya ledak otot tungkai $\left(\mathrm{X}^{2}\right)$ dengan variabel kemampuan $\operatorname{smash}(\mathrm{Y})$ sebesar $.308>\alpha 0,05$. Sehingga 
dapat diartikan bahwa data variabel $\mathrm{X}_{1}, \mathrm{X}^{2}$

dan Y semua data bervariansi homogen.

\section{Pengujian Hipotesis}

\section{a. Pengujian Hipotesis Pertama}

Tabel 4. Hasil Penghitungan Korelasi $\mathrm{X}^{1}$ dengan $\mathrm{Y}$

\begin{tabular}{|c|c|c|c|}
\hline Variabel & $\begin{array}{c}\mathrm{r}- \\
\text { hitung }\end{array}$ & Sig & $\alpha$ \\
\hline $\begin{array}{c}\mathrm{X}_{1} \text { dengan } \\
\mathrm{Y}\end{array}$ & .417 & 0.000 & 0.05 \\
\hline
\end{tabular}

Berdasarkan Tabel 4 diperoleh variabel daya ledak otot lengan dengan kemampuan smash dari output nilai sig sebesar $0.000<\alpha$ 0.05. Maka dapat dinyatakan bahwa ada hubungan yang signifikan antara daya ledak otot lengan terhadap keberhasilan dalam melakukan smash pada atlet bola voli di Ma AL-Riyad dengan koefisien korelasi yang cukup kuat $(\mathrm{r}=4.17)$.

\section{b. Pengujian Hipotesis Kedua}

Tabel 5. Hasil Penghitungan Korelasi $\mathrm{X}^{2}$ dengan $Y$

\begin{tabular}{|c|c|c|c|}
\hline Variabel & $\begin{array}{c}\mathrm{r}- \\
\text { hitu } \\
\mathrm{ng}\end{array}$ & Sig & $\alpha$ \\
\hline $\mathrm{X}_{2}$ dengan $\mathrm{Y}$ & .6 & 0.000 & 0.05 \\
& 12 & & \\
\hline
\end{tabular}

Berdasarkan Tabel 5 diperoleh variabel terdapat korelasi antara daya ledak otot tungkai dengan kemampuan smash dari output nilai sig sebesar $0.000<\alpha 0.05$. Maka dapat dinyatakan bahwa ada hubungan yang signifikan antara daya ledak otot tungkai terhadap keberhasilan dalam melakukan smash pada atlet bola voli di Ma AL-Riyad dengan koefisien korelasi yang kuat $(\mathrm{r}=612)$.

\section{c. Pengujian Hipotesis Ketiga}

Tabel 6. Hasil Penghitungan Korelasi $\mathrm{X}^{1}$, $\mathrm{X}^{2}$ dengan $\mathrm{Y}$

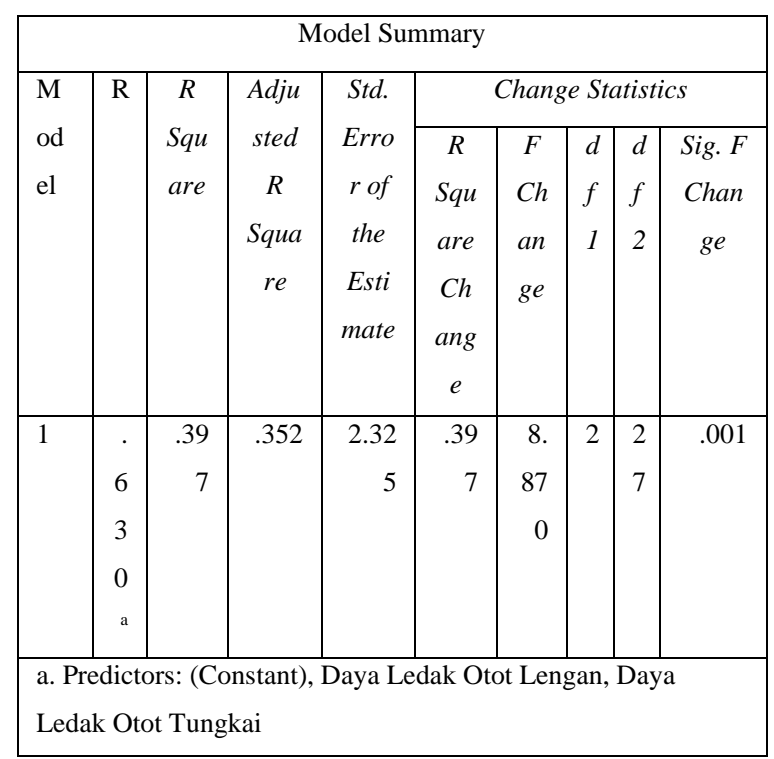

Berdasarkan Tabel 6 Model Summary menunjukan bahwa besarnya korelasi bersamaan antara daya ledak otot lengan dan daya ledak otot tungkai dengan kemampuan smash dihitung dengan koefisien korelasi adalah 0.630 atau $\left(\mathrm{R}^{\mathrm{yx} 1 \times 2}\right.$ $=0.630)$ hal ini menunjukan korelasi yang kuat.

\section{Simpulan}

Berdasarkan hasil penelitian dan pembahasan, maka pada bagian ini penulis dapat mengambil kesimpulan sebagai berikut :

1. Ada hubungan yang signifikan antara daya ledak otot lengan terhadap keberhasilan dalam melakukan smash pada atlet bola voli di Ma AL-Riyad. 
2. Ada hubungan yang signifikan antara daya ledak otot tungkai terhadap keberhasilan dalam melakukan smash pada atlet bola voli di Ma AL-Riyad.

3. Ada hubungan yang signifikan secara bersamaan antara daya ledak otot lengan dan daya ledak otot tungkai terhadap keberhasilan dalam melakukan smash pada atlet bola voli di Ma AL-Riyad.

\section{DAFTAS PUSTAKA}

Ahmadi, Nuril. (2007). Panduan Olahraga

Bola Voli. Surakarta : Era Pustaka Utama.

Arikunto, S. (2010). Prosedur penelitian : Suatu Pendekatan Praktik. (Edisi Revisi). Jakarta : Rineka Cipta. Ahmadi, Nuril. (2007). Panduan Olahraga Bola Voli. Surakarta: Era Pustaka Utama.

Arikunto, Suharsimi. (2010). Prosedur Penelitian Suatu pendekatan praktik. Jakarta: PT Rineka Cipta.
Muhamad Syamsul Taufik (2019) Hubungan Tingkat Konsentrasi Dengan Keterampilan Bermain Futsal Unit Kegiatan Mahasiswa Futsal Universitas Suryakancana Gladi: Jurnal Ilmu Keolahragaan Jilid 10 Terbitan 02 Halaman 68-78 Muhamad Syamsul Taufik (2014) Hubungan Antara Indeks Massa Tubuh, Fleksibilitas Dan Kecepatan Reaksi Dengan Kelincahan Pada Cabang Olahraga Futsal Lembaga Universitas Pendidikan Indonesia Nurhasan, cholil Hasanudin. (2007). Modul Tes dan Pengukuran Keolahragaan. Bandung : FPOK

Nurhasan \& Setiawan E. (2017). Tes, Pengukuran dan Evaluasi Pendidikan Jasmani dan Olahraga. Pendidikan Jasmani Unsur.Cianjur. Sugiyono. (2016). Metode Penelitian Pendidikan Pendekatan Kuantitatif, kualitatif, dan $R \& D$. Bandung: Alfabeta. 